\title{
Spontaneous Onset of Labor
}

National Cancer Institute

\section{Source}

National Cancer Institute. Spontaneous Onset of Labor. NCI Thesaurus. Code C113490.

Labor without the use of pharmacological and/or mechanical interventions to initiate labor. Does not apply if artificial rupture of membranes is performed before the onset of labor. (reVITALize) 